Article

\title{
Cultural Perspective of Traditional Cheese Consumption Practices and Its Sustainability among Post-Millennial Consumers
}

\author{
Zanete Garanti * (D) and Aysen Berberoglu \\ Department of Business Administration, Faculty of Economics and Administrative Sciences, \\ Cyprus International University, Lefkosa 99258, North Cyprus; aysenb@ciu.edu.tr \\ * Correspondence: zgaranti@ciu.edu.tr; Tel.: +90-533-850-5809
}

Received: 17 July 2018; Accepted: 3 September 2018; Published: 6 September 2018

\begin{abstract}
Background: The consumption of traditional foods has been linked to economic, social, and environmental sustainability; therefore, the main challenge of a changing marketplace is to ensure that young generations continue consuming traditional products. The current study uses a consumer culture theory (CCT) perspective to examine the following: (1) the way individuals use their traditional products to identify themselves with the culture and to feel that they are a part of the community, (2) the underlying values that turn young consumers into loyal customers of hellim/halloumi cheese, and (3) its implications to hellim/halloumi producers. (2) Methods: A qualitative research method is applied to study the perceptions of post-millennials towards traditional cheese products from a cultural perspective. (3) Results: The results of the study reveal that loyalty towards traditional food products amongst post-millennials is build based on (1) the memories that surround the food, (2) the rituals that preparing and eating a food involve, and (3) the identity that it builds, allowing people feel sense of belonging to their ethnic group. (4) Conclusions: Loyalty amongst post-millennials towards traditional food products tends to be emotional, rather than rational or behavioral. It allows us to present both theoretical and managerial implications. It also calls for more empirical research to understand the changing marketplace and post-millennials' consumption habits.
\end{abstract}

Keywords: consumer culture theory; post millennials; cheese; loyalty; Cyprus; traditional food

\section{Introduction}

Traditional food products are often recognized by means of association with their regional identity [1] and have always played an important role in the European, especially Mediterranean, culture, diet, and economy. As the new consumer generation of post-millennials is emerging, the biggest challenge for the marketplace [2] is to ensure progress that is proficient, so as to ensure that the current needs for an intact environment, social justice, and economic prosperity are met, without restraining the capacity of future generations to satisfy their desires [3]. The social sustainability [4] of traditional food is addressed in the current article, which focuses on traditional cheese product consumption amongst young consumers.

"How do you like your hellim/halloumi?" might sound like a silly question to some, but for Cypriots it is not a joke. With so many options available, everyone has their own favorite. Known as hellim in the Turkish Republic of Northern Cyprus, and halloumi in the Republic of Cyprus, this hard, rubbery, salty cheese represents the history and culture of the Mediterranean island. Recently, a battle to register hellim/halloumi cheese as protected designation of origin (PDO) in the European Union has led to many discussions to clarify who does the hellim/halloumi belong to. Being associated either 
with Greek or Turkish name, etymologically, the term halloumi points to an Arabic root, and cultural historians insist that the Venetian sources that had encountered halloumi in the pre-Ottoman period [5], originated from Egyptian and Roman civilizations [6].

Traditional food products can be defined based on the following four dimensions: (1) the key production process must be performed in a certain geographical area (national, regional, or local); (2) the recipe of the traditional food product must be authentic in terms of ingredients, raw materials, and the production process; (3) the traditional food product must have been traded for at least 50 years; and (4) it must be part of the gastronomic heritage [7]. Interestingly, hellim/halloumi cheese has many varieties available on the market, which is a rare phenomenon accruing in a case of a traditional food. Innovations in traditional food first might seem like a controversial phenomenon [8], but both the internal and external market demands, as well as industrial developments, impose innovations in traditional food products [9-11]. The innovations in food production in general and hellim/halloumi production in particular, did not interfere with the authenticity of hellim/halloumi, still allowing us to consider hellim/halloumi a Cypriot traditional food product. Firstly, it can only be produced in Cyprus. Secondly, while reaching an agreement on PDO, both sides of the island agreed that, historically, there are two major types of halloumi, fresh and mature. To secure the originality of hellim/halloumi cheese, it is defined that materials used in the production are fresh milk (sheep, goat, and cow), rennet, and fresh or dried Cypriot mint leaves and salt. It is also defined that the proportion of sheep or goat's milk, or the mixture thereof, must always be greater than the proportion of cow's milk [12]. The regulation allows for many varieties of cheese to be produced, for example, hellim/halloumi from $100 \%$ goat milk or $100 \%$ sheep milk, or mixed milk, or hellim/halloumi with or without mint, as well as differentiating salt levels, to name a few, without losing the authenticity of the traditional hellim/halloumi cheese. Thirdly, it has it has been produced and sold in island for centuries. Traditionally produced in rural areas by groups of women, hellim/halloumi production was seen as a social communal collaboration up until the 1970s [13], but as a result of industrial developments, hellim/halloumi producing acts in villages are rare. There are 53 industrial halloumi producers in southern Cyprus and 34 producers in the north [14], with the first factory producing hellim/halloumi in north being opened in 1958 [15], meaning that hellim/halloumi was commercialized around 60 years ago. Finally, it is also a gastronomic heritage with high consumption rates.

Traditional food products, especially the ones applying qualification and indication schemes, are known for the following: to promote the culture and traditions of the place of origin by using traditional practices of production [16-18]; to secure the originality of local foods $[19,20]$ that are assumed to have greater health benefits [21]; are anticipated to act as a guarantee of the quality and safety by linking the quality attributes to foods 'locality' [16,22-25]; and can promote local communities, and support rural development [22,26-28], protecting rural areas from depopulation [1]. Hellim/halloumi cheese production is the major industry in Northern Cyprus, and is the main export product, according to the Cyprus Turkish Chamber of Industry [29]. We argue than hellim/halloumi cheese is one of the heathiest cheese options, firstly, because its recipe [12] does not allow for the use of any preservatives and additives, and secondly, because it uses fresh, local milk [30] that has traces of the wild plants that the animals have eaten [31]. More importantly, hellim/halloumi production uses an estimated $89 \%$ of the sheep and goat milk that is produced in the island [32], which gives hellim/halloumi its specific taste and aroma. As the price of the milk in Cyprus is the highest in the region [33], producing any other types of dairy products would not be as sustainable, because its price would not be competitive.

Traditional foods are typically consumed by middle-aged, ethnocentric, health-conscious select locals [34], which is not a case in Cyprus, where hellim/halloumi cheese is characterized by very high local consumption rates [14], even higher than the modern imported cheeses. In this paper, the authors aim to understand how loyalty towards traditional foods are built amongst young consumers, as previous research shows that younger customers are more concerned about emotional attachment and experiences $[35,36]$ rather than the attributes of products and services. Therefore, the authors use a consumer culture theory (CCT) perspective to examine the following: (1) the way 
individuals use their traditional products to identify themselves with the culture and feel that they are a part of the community, (2) underlying values that turns young consumers into loyal customers of hellim/halloumi cheese, and (3) its implications to hellim/halloumi producers.

This research contributes to the existing knowledge in multiple ways. Firstly, it uses the perspective of CCT to understand more the complex aspect of loyalty that builds as a result of social and cultural experiences. Previously, Collin-Lachaud and Kjeldgaard [37] underwent one of the first studies that looked into a loyalty concept from a culturally informed perspective, using the attendees of music festivals as their study sample, but to the best of the authors' knowledge, there was no empirical evidence using a CCT perspective to explain loyalty in the traditional food industry. Moreover, the current study specifically explores the cultural aspect of loyalty building amongst young consumers, as previous research has identified the need for additional research [38] in order to understand transcend boundaries of consumption amongst different generations. In this study, we focused on post-millennials, also called Gen Z, who are classified as individuals are born after 1997 [39], mainly because they are the emerging market share, recently entering adulthood, and not much is known about their consumption habits. Finally, it brings out the managerial implications for the hellim/halloumi producers in Cyprus who are trying to establish long term loyalty relationships with their customers, and focusing on Gen $\mathrm{Z}$ as a large, emerging market segment.

\section{Theoretical Background}

In the field of consumer research, increasing interest is devoted to studying the marketplace phenomena from individuals' cultural perspectives [40], rather than focusing solely on the economic and psychological motivators and drivers of consumption. CCT explains how consumption experiences are shaped by "dynamic relationships between consumer actions, the marketplace, and cultural meanings" [41], and emphasizes the importance of consumption in the "construction of individual identities" [42]. When it comes to consuming traditional foods, consumers are driven by multiple factors of influence, far beyond the economic and psychological motivators known in the traditional literature of consumer behavior. Consumer culture theory summarizes the sociocultural, experiental, symbolic, and ideological aspects of consumption.

When the literature from the last 20 years is reviewed, it is possible to conclude that this concept has been sought over the years, but its conceptualization was made by Arnould and Thompson [41]. Contemporary consumer culture theory is a concept unifying the consumer actions, the marketplace, and cultural meanings together, while analyzing consumer behavior; in other words, taking into consideration all of the variables like the sociocultural, experiential, symbolic, and ideological aspects of consumption [41].

Throughout the years, consumption has retained its importance in terms of sociology, economics, and business literature, however, now the term is evaluated on the basis of the relations between the society and the individual, as a form of social classification, and communications systems, as a way to identity formation, ritualistic and community building processes, the relationship between the individual and the state, or the search for existentially fulfilling experiences [43]. However, over the years, marketing and consumer research literature had been limited to macro level perspectives, and marketing research did not focus on broader social, cultural, and macro-level considerations [44].

Early CCT suggestions objected the limitation of consumption to demographic or psychographic properties of consumers, like their gender, age, personality, or lifestyle traits, however, after the 1980s the CCT definition began to involve humanistic and experientialist paradigms, and CCT became attached to the "consumption experiences and the personal meanings" that consumers develop to products and experiences [45].

According to Schouten and McAlexander [38], consumer culture theory plays a very important role in the marketing discipline, because the interpersonal relationships people undertake to give their lives meaning is very crucial, for instance, by choosing how to spend their money and their time-while doing this they create their own categories, which is called the subcultures of consumption. 
Consumer culture theory is significant in terms of consumer behavior, because its focal point is the meaning and identity creation in terms of products, brands, and experiences; it is related to the mentality created by the consumers in the marketplace, and the underlying reason for this mentality can be used to engage the attention of buyers and sellers.

In general business studies, culture is defined as a homogenous structure, including the meanings, ways of life, and shared values that affect the behavior of its members [45]. However, on the other hand, CCT does not acknowledge culture as its common definition, which is the "homogenous system of collectively shared meanings, ways of life, and unifying values shared by a member of society", but CCT is interested in investigating the heterogeneous allocation of meanings and the reasons for overlapping cultural groupings. Thus, consumer culture theory indicates a social arrangement as a result of the bonds between lived culture and social resources, meaningful ways of life, and the symbolic and material resources on which they depend [41]. Continuously, CCT does not detect and structure the behavior, but rather interprets the consumers' reactions or feelings based on patterns of behavior [45].

An important aspect within CCT is identity building by consumers. According to Patterson et al. [46], CCT claims that the marketplace involves ample amounts of commodities and symbolic resources to be used by consumers in terms of identity construction. Moreover, the study of culture in the marketplace indicates that the collective identity of consumers is created through an engagement in common consumption interests [46].

Consecutively, another important dimension of consumer culture theory is the 'experience', which refers to the phenomenon of the story behind the consumers relations with the products or brands. According to Ahola [47], it is possible to conceptualize the 'experience' in three dimensions within CCT. The first dimension is named the 'humanistic frame', in which the experience of the consumer is a personally unique event that is associated with significant emotional experiences, a kind of more inner phenomenon. The second one is called 'extraordinariness', where an "extraordinary experience is activated by unusual events and is characterized by high levels of emotional intensity and experience". The last framed is named the 'marketplace frame', where the main question is "how are the meanings of experience formed in the marketplace?" [47].

When the extant literature is reviewed, it is possible to come across many studies regarding consumer behavior, however, not many of the studies are grounded on consumer culture theory. Usually, the studies are looking at the individual consumer experiences or meanings rather than trying to reveal the culture created by a distinctive group of consumers.

One of the earliest studies in the literature was carried out by Schouten and McAlexander [38]. In their study, the authors considered the subcultures of consumption "as a distinctive subgroup of society that self-selects on the basis of a shared commitment to a particular product class, brand, or consumption activity, including an identifiable, hierarchical social structure; a unique ethos, or set of shared beliefs and values; and unique jargons, rituals, and modes of symbolic expression".

A later study by Arnould and Thompson [41], was the first to clearly define the consumer culture theory, which had a significant contribution to the literature.

Lastly, another recent study that was carried out by Collin-Lachaud and Kjeldgaard [37], grounded their research on the theory of consumer culture. The study considered the concept of loyalty from a consumer culture theory perspective. While evaluating the annual (French) music festivals and their ritualized meanings for consumers, they addressed the loyalty from perspectives of (1) social rather than individual, (2) an outcome of a social evaluation of emotional experiences rather than individual satisfaction, (3) temporally, and (4) spatially structured and structuring.

\section{Research Context}

The world milk production has increased by $64 \%$ from 1970 to 2012 . A large part of this expansion has been used to increase the cheese production in all regions of the world. Innovations, new product development, and increased demand from emerging economies [48] have led to a higher than ever 
cheese consumption. Germany, the Netherlands, and France are the main cheese exporters in the world, and each exported more than $\$ 3$ billion worth of cheese in 2015 [49]. The top cheese consumer is Denmark, where the people consume $28.1 \mathrm{~kg}$ of cheese per capita in a year. The second highest consumer is Iceland, followed by Finland, with $27.7 \mathrm{~kg}$ and $27.3 \mathrm{~kg}$ cheese consumption per capita, respectively [50].

As a product that holds geographical indication, hellim/halloumi cheese can be only produced in Cyprus (both northern and southern Cyprus). As the focus of this paper is the consumers in northern Cyprus, the growth of hellim/halloumi cheese production has been analyzed. The total milk product produced in northern Cyprus has significantly increased since 1995 (Figure 1), mostly due to the demand from domestic and external markets, as extensive marketing campaigns towards hellim/halloumi cheese were undertaken by the Cyprus Turkish Chamber of Industry, producers, and other stakeholders.

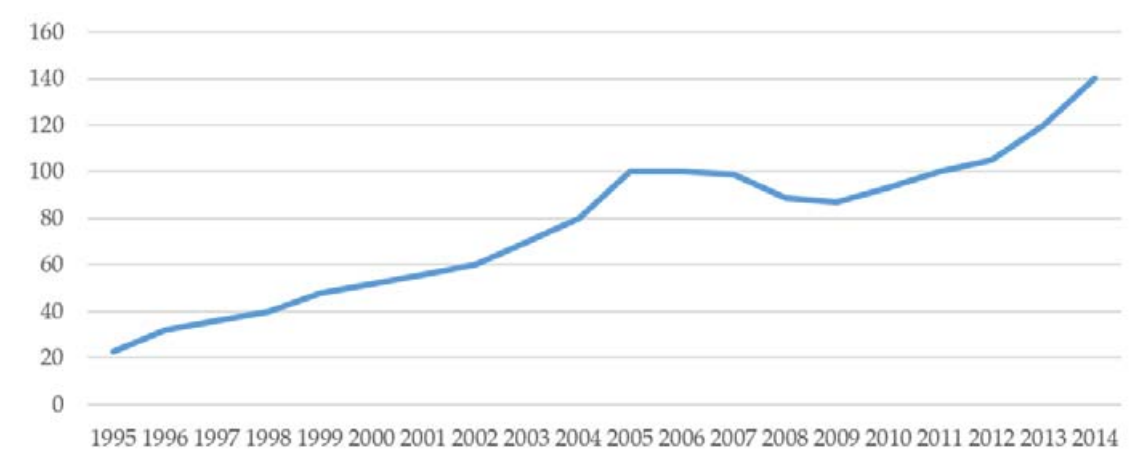

Figure 1. Total milk product production in Northern Cyprus (million tons). Source: the Cyprus Turkish Chamber of Industry.

Hellim/halloumi exports made up 22\% of the total exports from Northern Cyprus in 2014. The export values have increased by $33 \%$ in the analyzed time period (Figure 2), mainly due to price increases and an increased demand from the market.

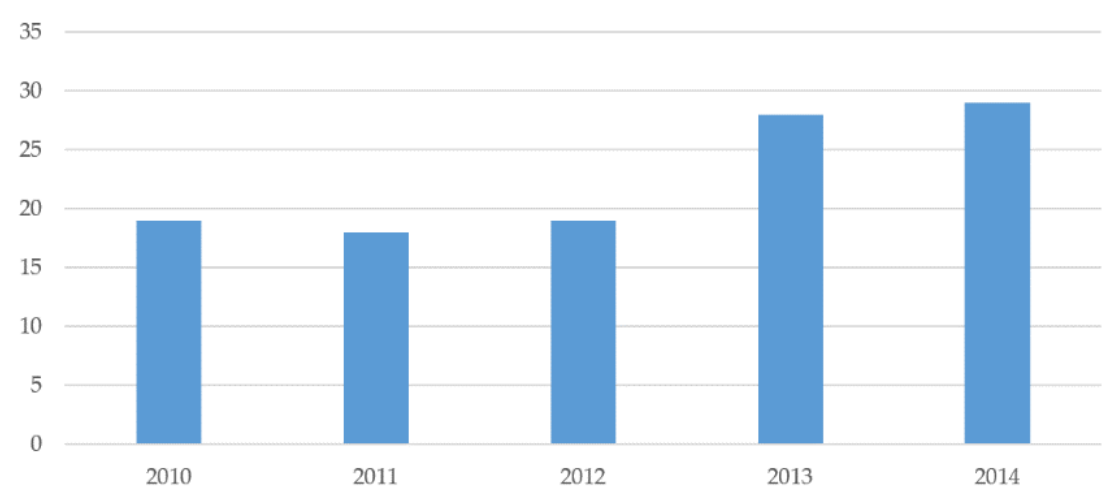

Figure 2. Hellim/halloumi exports from Northern Cyprus (million US dollars). Source: the Cyprus Turkish Chamber of Industry.

The major hellim/halloumi export countries are Kuwait, Saudi Arabia, and Turkey (Figure 3), where hellim/halloumi is known, and the exports significantly increased since the Cyprus Turkish Chamber of Industry obtained the geographic indication of hellim/halloumi, allowing for production only to take place in Cyprus.

Although the majority of hellim/halloumi is exported to the Middle East, there is also a significant amount of hellim/halloumi exported to the United Kingdom, Australia, and the United States, where a majority of Cypriots now live after war in 1974. In addition, a significant part of hellim/halloumi 
is consumed in the domestic market. According to the Cyprus Turkish Chamber of Industry [29], in Northern Cyprus, people consumer around $12 \mathrm{~kg}$ of hellim/halloumi per capita in a year, which is more than any type of imported cheese, showing the importance of this traditional product in consumers' choices.

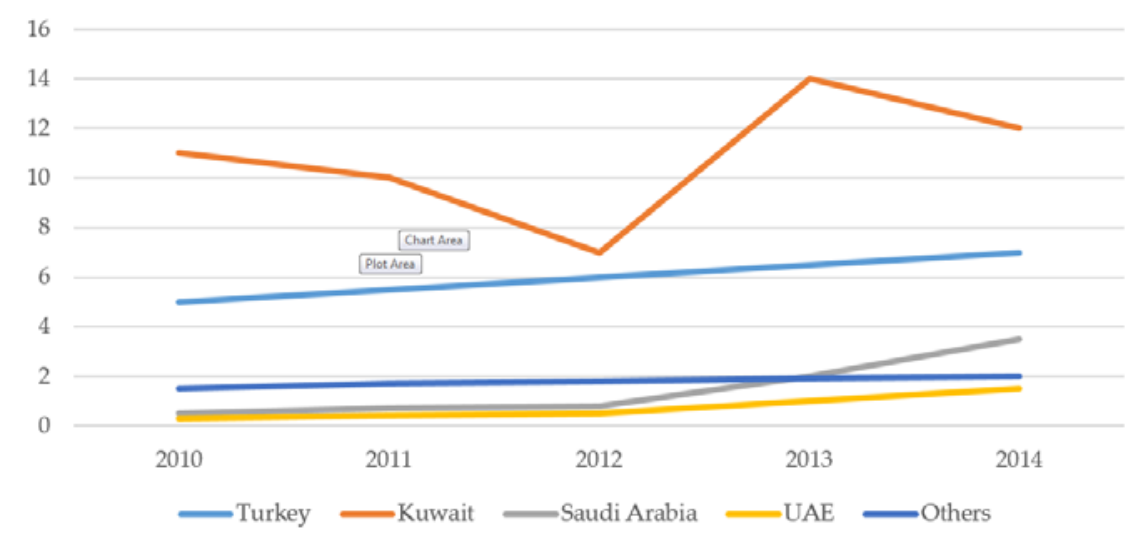

Figure 3. Hellim/halloumi export countries (million US dollars). Source: the Cyprus Turkish Chamber of Industry.

\section{Methodology}

The authors aimed to describe and clarify human experiences as it appears in people's lives, using a qualitative approach [51], as the field, rather than the laboratory, is the natural context for CCT research [41]. In order to achieve the aims of this study, the authors conducted semi-structured interviews, which were audio-recorded and transcribed. Purposive sampling was used to select the participants for the semi-structured interviews, as suggested by Teddlie and Yu [52], and Tongco [53]. More specifically, a homogeneous sampling technique was applied [54] in order to answer the research question that is aimed at understanding and explaining the consumption practices among the post-millennial generation. To define the sample size, the authors followed the suggestion of Guest, Bunce, and Johnson [55], who propose that saturation occurs in around 12 participants in homogeneous groups. A similar sample size is used in various qualitative researches [56-58]. After the first ten interviews, the authors recognized that the information given starts to repeat, and there are no new insights brought. Finally, a sample of 12 participants was included, and the main criteria was that the participants belonged to the post-millennials generation (also referred as Gen Z), defined as individuals born after 1997 [39], and had reached the age of 18 at the time of interview. Each of the interviews lasted up to an hour. The profiles of the respondents are represented in Table 1.

Table 1. Profile of interviewees.

\begin{tabular}{cccc}
\hline Interviewee & Gender & Birth Year & Occupation \\
\hline 1 & Male & 1999 & Working in a family business \\
2 & Male & 2000 & Student \\
3 & Female & 1997 & Working \\
4 & Male & 1999 & Student \\
5 & Female & 1998 & Student/part time working \\
6 & Female & 1999 & Establishing business \\
7 & Male & 1999 & Student \\
8 & Female & 1997 & Student \\
9 & Female & 1999 & Student \\
10 & Male & 1998 & Student/part time working \\
11 & Male & 2000 & Student \\
12 & Female & 1999 & Student/working in family business \\
\hline
\end{tabular}


Firstly, the participants were asked to describe the attributes of ideal hellim/halloumi cheese, based on given criteria (price, taste, freshness, milk used in production, odor, traditional recipe used, origin, and production method). Then, questions were asked in order to understand the building blocks of the cultural and emotional attachment towards hellim/halloumi cheese and the consumption habits that build loyalty towards hellim/halloumi cheese. The detailed set of questions that were asked in order to evaluate the consumption practices of traditional hellim/halloumi cheese amongst post-millennials can be found in Appendix A.

Data triangulation has been applied in order to facilitate the validation and reliability of the collected data, as well as to facilitate a comprehensive understanding of the phenomena [59]. Apart from focused observations and semi-structured interviews, the author used theoretical data gathered from relevant sources, as well as newspapers, magazines, and documentation regarding hellim/halloumi cheese. Content analysis, defined as "a subjective interpretation of text data through systematic classification process of coding and identifying themes or patterns" by Hsieh and Shannon [60], was then applied to analyze the outcomes of the research.

\section{Results}

\subsection{Memories That Surround the Food}

Memories have an important role in assessing food and its taste [61], and in affecting the present eating practices [62]. Post-millennials are in their early 20's, but their hellim/halloumi consumption is hugely affected by memories of their family, especially of their ancestors, friends, and others. First of all, almost all of the interviewees had some memories of hellim/halloumi being produced in villages by their grandparents.

"I have never made it myself, but I have seen my grandma doing it. The process looks so complicated" (Female, born in 1999).

"My grandma always made hellim. She prepared it in spring time, as it is the season of the best goat and sheep milk. Then she stored in in big bottles, and served to everybody" (Male, born in 2000).

"I think those times there was not much choices in the supermarkets. Everybody made hellim at home" (Male, born in 1998).

As seen in the previous quotes, young Cypriots have an understanding of the hellim/halloumi production process and the milk used, because they have witnessed it from their ancestors. Moreover, two of the respondents living in villages have been involved in hellim/halloumi production, which allows young individuals to experience the cultural act themselves.

"I was helping my grandma to make hellim when I was a kid. I can still make. Actually, in my family we are still doing it sometimes" (Male, born in 1999).

"We have always been keeping our own animals for milk and meat purposes. First it was my grandma making hellim. She taught it to my mom. And my mom taught it to me and my sister. Every season, around April, we produce our hellim. It the best time because the milk is fatty. Hellim becomes hard, heavy and strong taste" (Male, born in 1999).

The post-millennials that have been involved in hellim/halloumi production have a deep understanding of all of the factors that affect the taste of hellim/halloumi, as it is shared knowledge amongst multiple generations. Also, the post-millennials, although consuming modern varieties of hellim/halloumi that is purchased in stores, have distinct memories regarding the taste of mature (referred to as 'old') hellim/halloumi, as described in the quotes below. 
"In general, there are two main types of hellim- fresh and mature. Nowadays, we are mostly eating the fresh hellim that is purchased from supermarkets. It tastes mild, salty and rubbery. But I remember in my childhood our grandma always served mature hellim to us. It is very hard, salty cheese that has a goat milk aroma. I used to eat it when I was a kid, but now the taste is just too strong for me" (Female, born in 1997).

"You can use old hellim with macaroni dishes, but really the taste is too much. I prefer fresh, packaged hellim for my everyday use" (Male, born in 1999).

Understandably, the younger generations are not very familiar with the 'old' taste of this traditional product, as they have mostly consumed modernized variations of hellim/halloumi, therefore, the taste of mature hellim/halloumi, although familiar, is too strong for post-millennials, who prefer milder, softer varieties of hellim/halloumi.

\subsection{Food That Is a Ritual}

Rituals are actions that are frequently repeated [63], and make distinction between primitive understandings of food as a fuel for the body to more symbolic meanings of consumption [64]. Preparing and eating a food is a social act, shared with family, friends, and other people around, which allows one to feel sense of belonging an inclusion [65]. Post-millennials have developed their own rituals that involve hellim/halloumi as a distinctive and integral breakfast food, as well as a central ingredient in several other traditional foods.

"Since I was small, I saw from my dad. He was always buying hellim and we were using it in sandwiches. Every morning before school he was making us sandwich or toast with hellim and tomatoes. I still use it the same way" (Female, born in 1998).

"When you light your barbeque and people are coming over for lunch or dinner, it is impossible not to serve grilled hellim in pita bread. It is an essential part of a barbeque party" (Male, born in 2000).

"Since we are small kids, my mom always cooks macaroni with chicken, and puts graded hellim on the top. The smell of that food fills the house and it makes you feel so good. If one cook it at home, the smell fills up all the village, and always I had all my friends over for lunch that day" (Female, born in 1999).

Hellim/halloumi, as mentioned by the interviewees, is essential part of breakfast, lunch, and dinner that is shared amongst friends, family, and other people. Currently, the majority of post-millennials are still living with the families, and do not have their own households. Therefore, as admitted by many, purchasing hellim/halloumi is done by their parents. When asked if they would continue to purchase hellim/halloumi even when having their own household, the answers were positive.

“Of course, I would continue to buy it. I don't want my kids to grow up and not know the taste of hellim sandwich or fried hellim" (Female, born 1999).

Unanimously, the post-millennials agreed that hellim/halloumi is a food that they would like to continue using in their own houses, and they would teach consuming hellim to their children, therefore the rituals surrounding hellim/halloumi seem to be sustainable. 


\subsection{Food That Builds Identity}

Identity is "that part of an individual's self-concept which derives from his knowledge of his membership of a social group (or groups) together with the value and emotional significance attached to that membership" [66]. People have a tendency to attach symbolic meaning to the foods that they consume, especially in the case of traditional foods [67]. Moreover, according to Fischler, [68] "food is central to our sense of identity". Identity building is acknowledged to be a dynamic process [69] accumulating and changing over time. The hellim/halloumi consumption process seems to be an identity builder for the Turkish Cypriot post-millennials, who admit the following:

"Hellim is very important. I mean, I cannot imagine my life without hellim" (Female, born in 1999).

"Without hellim it is not possible" (Male, born in 2000).

"Hellim is not just a food. Hellim is Cypriot" (Male, born in 1998).

These quotes describe how young Cypriots recognize that what they eat actually is a construct of what they are. Young people, especially the ones belonging to the post-millennial generation, are often seen as technologically inclined, and belonging to the most global generation, while this is not the true when it comes to consuming food. Post-millennials love their traditional food and, interestingly, pay a lot of attention to what they consume and how they consume, developing a value of the food, that allows them to identify themselves with it.

Another aspect of identity building, which is reflected in the below mentioned quotes, allows us to have a deeper understanding on how hellim/halloumi allows people to identify themselves as a Cypriots:

"When my aunty comes from London for her summer holidays in Cyprus, first thing we always serve is hellim with watermelon. And when she goes back, she always takes a lot of hellim with her" (Male, born in 2000).

"If I travel somewhere, I need my hellim with me" (Female, born in 1997).

As seen in the previous quotes, hellim/halloumi is carried to different locations and has an almost symbolic meaning that allows one to feel and sense Cyprus even when abroad. Nevertheless, hellim/halloumi consumption is seen as an act that can differentiate the Turkish Cypriots from other nationalities that have a huge political and economic influence in the island of Cyprus, as follows:

"Hellim is the only thing differentiating us from Turkish people. What else do we have? Nothing" (Female, born in 1999).

"We speak Turkish. We eat Turkish food. We have Turkish people in this island more than we have Cypriots. We watch Turkish TV. We listen to Turkish music. I don't know, we are always, you know, always seen as being Turkish. When we pass to Greek side, they call us Turks. I mean, hellim, hellim is something else. When you go to Turkey and say you are from Cyprus, they immediately recall hellim, because it is something to do with Cyprus, not Turkey" (Male, born in 1998).

In the above quotations, a strong willingness of young people to be identified with their ethnic group, Turkish Cypriots, rather than Turkish, has been expressed. With Turkey being a 'mother country' [70] and the political, economic, and social burdens that Turkish Cypriots face, their food has become their identity that distinguish them from harsh influences. 


\section{Conclusions and Discussion}

Loyalty towards traditional foods is not a well explored field in academic literature, especially from a cultural perspective. From the insights obtained from the interviews amongst young consumers (referred to as post-millennials or Gen Z), the current research allows us to supplement and to progress the understanding of loyalty towards traditional food products from a consumer culture theory perspective.

According to the responses of the interviewees, it is possible to conclude that hellim consumption is the part of the culture that they belong to, an inevitable piece of their rituals, and it is transmitted from old generations to new ones. Looking from a consumer perspective, hellim as a product, has a significant place in the minds of customers and it is an unchanging complement of specific consumption behaviors.

There is no doubt that young consumers are driven by the sociocultural and symbolical motivators for the hellim consumption as a result of their 'learnt' experiences from their ancestors. Post-millennials had attributed meaning to their hellim consumption, each unique to their own, after their experiences from their childhood. Their interpersonal relationships with their family and their experiences with hellim consumption are the great drivers for deciding how to spend their money (on hellim). These experiences can be explained as "personally unique events that are associated with significant emotional experiences" [47].

As specified in the existing literature, consumption behaviors are a way of distinct identity construction of consumers/consumer groups. Food as a trade product is related to the economy and to consumption practices, whereas food as a sign of culture, is related to tradition, identity, and uniqueness, and it is possible to say that it can be used in the construction of personal identities [71]. Presently, in the situation of the Turkish Cypriot community, the way food is produced, served, and consumed can be a sign of a distinct identity and the culture of an individual, community, or nation [72]. While food and drink can be indicators of group culture and identity, because it says something meaningful about people, it can be considered as an often open-ended process of social identification [73]. However, on the other hand, while food can gather people together with the similar tastes and preferences, it can also divide people based on their dietary and religious preferences, which also contributes to identity creation [72]. This can be an example of how the Turkish Cypriot community is differentiating themselves from the Turkish community, by consuming the traditional hellim/halloumi cheese.

Undeniably, traditional foods play an important role in the economic, social, and environmental sustainability. Therefore, loyalty towards traditional foods is the key driving factor to ensuring all aspects of sustainability, especially amongst young consumers, as they are the ones imposing significant changes in the market place. Firstly, as observed in the relevant literature [38,47], and in the current empirical investigation, loyalty towards traditional food products is build based on (1) the memories that surround the food, (2) the rituals that preparing and eating a food involve, and (3) the identity that it builds, allowing people feel sense of belonging to their ethnic group. Our findings confirm the previous outcomes of Collin-Lachaud and Kjeldgaard's [37] research, which confirmed loyalty as being a social and emotional process, rather than behavioral.

It is possible to explain this situation by a CCT perspective, whereby culture is not defined as only "homogenous system of collectively shared meanings, ways of life, and unifying values", but the "heterogeneous allocation of meanings and the reasons of overlapping cultural groupings" [41].

Understanding the mentality behind hellim consumption is important for companies in order to engage buyers to consume their own product brands. An example can be given from answers of the interviewees, where the post-millennials like to consume the new kind of hellim, however they find the traditional old hellim as an inevitable complementary for some meals. While some like the taste of the 'old' hellim and find the 'new' hellim to be 'rubbery', the others are more used to the taste of the new hellim. 
As discussed before, post-millennials do not select the most traditional type of hellim/halloumi cheese, which is 'old' hellim/halloumi in brine, giving preference to the modern varieties of the packaged and less salted hellim/halloumi, because of the milder and lighter taste and odor. It shows us that in the very near future, the market demand will drive producers to produce more of the modern varieties of hellim/halloumi, and less of the 'old' varieties. Firstly, there is the issue of production planning, as producers have to refocus from producing traditional varieties of hellim/halloumi, to producing modern varieties of the specialty cheese. Secondly, and most importantly, although innovations in traditional food products are a market driven process [8], it poses risks to traditional food products in sustaining its traditional taste, recipe, odor, and even the production method. Therefore, the Cyprus Turkish Chamber of Industry and other certification bodies and involved stakeholders have to pay additional attention to ensure the sustainability and originality of the hellim/halloumi cheese production methods and taste.

\section{Limitations and Suggestions for Future Research}

This particular study focuses on post-millennials as an emerging market segment, which is not a well explored sector in the literature currently. Not much is known about post-millennials, and we have built this study to understand the fundamentals of the consumption habits of young consumers, focusing only on the traditional product in particular geographical locations. Obviously, there is more to explore regarding loyalty amongst post-millennials, especially because they have just entered their adulthood and are becoming independent customers slowly.

The results of the current study should be evaluated with caution, as the current study is limited to only one particular region and traditional food product in this region. However, the results generated from the study provide a general overview of post-millennials and their consumption habits of traditional food from cultural perspective. Further studies extending to different product ranges apart from traditional products and different geographical locations are welcome.

For future research, we also suggest exploring post-millennials and their consumptions habits more in-depth. Firstly, we suggest exploring the building blocks that lead to brand equity and loyalty, like satisfaction, experience, service quality, and even emotional attachment. Studies dealing with how young consumers make purchase decisions would be highly appreciated.

Author Contributions: Introduction, Z.G. Theoretical background, A.B. Methodology, Z.G. Results and findings, A.B. and Z.G. Conclusions and discussion, Z.G. and A.B.

Funding: This research received no external funding.

Conflicts of Interest: The authors declare no conflict of interest.

\section{Appendix A. Sample Questions for Semi-Structured Interviews}

1. Background information, namley: age, family status, occupation, and current place of living.

2. How could you define hellim/halloumi? What does it mean for you? How important is hellim/halloumi for you, your family, and your country?

3. Is hellim/halloumi 'Cypriot'? Is it part of the Cypriot culture? Is it important for Cypriots? What other foods you can name that are also of a Cypriot origin?

4. How would you describe the taste of perfect hellim/halloumi cheese? How would you describe the odor of perfect hellim/halloumi cheese? How would you describe the texture of perfect hellim/halloumi cheese?

5. How do you normally consume hellim/halloumi? What are the foods you use it for? What is your favorite way to consume it? What foods do you prepare yourself, and what foods do others prepare for you? 
6. How do you use different types of hellim/halloumi in your household? Who likes mature hellim/halloumi? Who consumes fresh hellim/halloumi? Are there any differences between the hellim/halloumi preferences in your family? Which foods do you prefer with mature hellim/halloumi? Which foods do you prefer with fresh hellim/halloumi cheese?

7. How important is hellim/halloumi in your family? Is it part of some important family events/ food/traditions? Do you use it at your family gatherings? Do you use it as a gift for someone?

8. Who purchases hellim/halloumi in your household? Do you ever buy it? When you buy it, which type of hellim/halloumi do you prefer?

9. When you think of your childhood, what memories do you have regarding hellim/halloumi cheese? Has it always been part of your diet? Do you remember eating it when you were small? Do you remember the foods you were eating with hellim/halloumi? Do you remember who was preparing them?

10. Do you know how hellim/halloumi is prepared? Do you know the recipe of hellim/halloumi? Have you ever witnessed the hellim/halloumi production process? Have you ever been involved in the hellim/halloumi production process?

11. When you have your own family, will you continue to consume hellim/halloumi? Would you teach your kids to eat and prepare foods with hellim/halloumi?

\section{References}

1. Guerrero, L.; Guàrdia, M.D.; Xicola, J.; Verbeke, W.; Vanhonacker, F.; Zakowska-Biemans, S.; Sajdakowska, M.; Sulmont-Rosse, C.; Issanchou, S.; Contel, M.; et al. Consumer-driven definition of traditional food products and innovation in traditional foods. A qualitative cross-cultural study. Appetite 2009, 52, 345-354. [CrossRef] [PubMed]

2. Yi, Y.M.; Gim, T.H. What Makes an Old Market Sustainable? An Empirical Analysison the Economic and Leisure Performances of Traditional Retail Markets in Seoul. Sustainability 2018, 10, 1779. [CrossRef]

3. Bruntland, G.H. Our Common Future: The World Commission on Environment and Development; Oxford University Press: Oxford, UK, 1987.

4. Finkbeiner, M.; Schau, E.M.; Lehmann, A.; Traverso, M. Towards life cycle sustainability assessment. Sustainability 2010, 2, 3309-3322. [CrossRef]

5. Patapiou, N. Leonardo Donà in Cyprus. A Future Doge in the Karpass Peninsula (1557). Cyprus Today Q. Cult. Rev. Minist. Educ. Cult. 2006, 44, 3-18.

6. Osam, N.; Kasapoglu, U.M. Hallumi: The Origin Analysis of a Cultural Entity. Milli Folklor 2010, 87, 170-180.

7. Gellynck, X.; Kühne, B. Innovation and collaboration in traditional food chain networks. J. Chain Netw. Sci. 2008, 8, 121-129. [CrossRef]

8. Jordana, J. Traditional foods: Challenges facing the European food industry. Food Res. Int. 2000, 33, 147-152. [CrossRef]

9. Kühne, B.; Vanhonacker, F.; Gellynck, X.; Verbeke, W. Innovation in traditional food products in Europe: Do sector innovation activities match consumers' acceptance? Food Qual. Preference 2010, 21, 629-638. [CrossRef]

10. Żakowska-Biemans, S.; Sajdakowska, M.; Issanchou, S. Impact of innovation on consumers liking and willingness to pay for traditional sausages. Pol. J. Food Nutr. Sci. 2016, 66, 119-128. [CrossRef]

11. Di Monaco, R.; Cavella, S. Differences in liking of traditional salami: The effect of local consumer familiarity and relation with the manufacturing process. Br. Food J. 2015, 117, 2039-2056. [CrossRef]

12. European Commission. Available online: http://europa.eu/rapid/press-release_IP-15-5448_en.htm (accessed on 2 July 2018).

13. Welz, G. Contested Origins: Food Heritage and the European Union's Quality Label Program. Food Cult. Soc. 2013, 16, 265-279. [CrossRef]

14. Garanti, Z. Marketing Hellim/Halloumi Cheese: A Comparative Study of Northern and Southern Cyprus. Econ. Sci. Rural Dev. Conf. Proc. 2016, 43, 65-72.

15. Koop Milk. Available online: http:/ / www.koopsut.com (accessed on 15 August 2018).

16. Bowen, S.; Zapata, A.V. Geographical indications, terroir, and socioeconomic and ecological sustainability: The case of tequila. J. Rural Stud. 2009, 25, 108-119. [CrossRef] 
17. Bowen, S. Embedding local places in global spaces: Geographical indications as a territorial development strategy. Rural Sociol. 2010, 75, 209-243. [CrossRef]

18. Dokuzlu, S. Geographical indications, implementation and traceability: Gemlik table olives. Br. Food J. 2016, 118, 2074-2085. [CrossRef]

19. Stasi, A.; Nardone, G.; Viscecchia, R.; Seccia, A. Italian wine demand and differentiation effect of geographical indications. Int. J. Wine Bus. Res. 2011, 23, 49-61. [CrossRef]

20. Blackwell, M. The relationship of geographical indications with real property valuation and management. Prop. Manag. 2007, 25, 193-203. [CrossRef]

21. Adinolfi, F.; De Rosa, M.; Trabalzi, F. Dedicated andgeneric marketing strategies: The disconnection between geographical indications and consumer behavior in Italy. Br. Food J. 2011, 113, 419-435. [CrossRef]

22. Belletti, G.; Marescotti, A.; Vakoufaris, H. Linking protection of geographical indications to the environment: Evidence from the European Union olive-oil sector. Land Use Policy 2015, 48, 94-106. [CrossRef]

23. Josling, T. The war on terroir: Geographical indications as a transatlantic trade conflict. J. Agric. Econ. 2006, 57, 337-363. [CrossRef]

24. Zhao, X.; Kneafsey, M.; Finlay, D. Food safety and Chinese geographical indications. Br. Food Journal. 2016, 118, 217-230. [CrossRef]

25. Aggarwal, R.; Singh, H.; Prashar, S. Branding of geographical indications in India: A paradigm to sustain its premium value. Int. J. Law Manag. 2014, 56, 431-442. [CrossRef]

26. Donner, M.; Fort, F.; Vellema, S. From Geographical Indications to Collective Place Branding in France and Morocco. In The Importance of Place: Geographical Indications as a Tool for Local and Regional Development; Springer: Cham, Switzerland, 2017; pp. 173-196.

27. Belletti, G.; Marescotti, A.; Brazzini, A. Old World Case Study: The Role of Protected Geographical Indications to Foster Rural Development Dynamics: The Case of Sorana Bean PGI. In The Importance of Place: Geographical Indications as a Tool for Local and Regional Development; Springer: Cham, Switzerland, 2017; pp. 253-276.

28. Biénabe, E.; Marie-Vivien, D. Institutionalizing geographical indications in southern countries: Lessons learned from Basmati and Rooibos. World Dev. 2017, 98, 58-67. [CrossRef]

29. Cyprus Turkish Chamber of Industry. Available online: http://www.kibso.org/index.php/tr/ (accessed on 20 June 2018).

30. Preedy, V.R.; Watson, R.R.; Patel, V.B. Handbook of Cheese in Health: Production, Nutrition and Medical Sciences; Wageningen Academic Publishers: Wageningen, The Netherlands, 2013.

31. Osorio, M.T.; Koidis, A.; Papademas, P. Major and trace elements in milk and Halloumi cheese as markers for authentication of goat feeding regimes and geographical origin. Int J. Dairy Technol. 2015, 68, 573-581. [CrossRef]

32. Sutek. Available online: https:/ / www.sutek.org (accessed on 12 August 2018).

33. EU Prices of Raw Milk. Available online: https:/ / ec.europa.eu/agriculture/sites/agriculture/files/marketobservatory/milk/pdf/eu-raw-milk-prices_en.pdf (accessed on 15 August 2018).

34. Vanhonacker, F.; Lengard, V.; Hersleth, M.; Verbeke, W. Profiling European traditional food consumers. Br. Food J. 2010, 112, 871-886. [CrossRef]

35. Veloutsou, C.; McAlonan, A. Loyalty and or disloyalty to a search engine: The case of young Millennials. J. Consum. Mark. 2012, 29, 125-135. [CrossRef]

36. Nowak, L.; Thach, L.; Olsen, J.E. Wowing the millennials: Creating brand equity in the wine industry. J. Prod. Brand Manag. 2006, 15, 316-323. [CrossRef]

37. Collin-Lachaud, I.; Kjeldgaard, D. Loyalty in a Cultural Perspective: Insights from French Music Festivals. In Consumer Culture Theory; Emerald Group Publishing Limited: Bingley, UK, 2013; pp. 285-295.

38. Schouten, J.W.; McAlexander, J.H. Subcultures of consumption: An ethnography of the new bikers. J. Consum. Res. 1995, 22, 43-61. [CrossRef]

39. Thompson, M.L. Smartphones: Addiction, or Way of Life? J. Ideol. 2017, 38, 3-17.

40. Moisander, J.; Valtonen, A.; Hirsto, H. Personal interviews in cultural consumer research-post-structuralist challenges. Consum. Mark. Cult. 2009, 12, 329-348. [CrossRef]

41. Arnould, E.J.; Thompson, C.J. Consumer culture theory (CCT): Twenty years of research. J. Consum. Res. 2005, 31, 868-882. [CrossRef]

42. Catulli, M.; Cook, M.; Potter, S. Consuming use orientated product service systems: A consumer culture theory perspective. J. Clean. Prod. 2017, 141, 1186-1193. [CrossRef] 
43. Askegaard, S.; Linnet, J.T. Towards an Epistemology of Consumer Culture Theory: Phenomenology and the Context of Context. Mark. Theory 2011, 11, 381-404. [CrossRef]

44. Fitchett, J.A.; Patsiaouras, G.; Davies, A. Myth and ideology in consumer culture theory. Mark. Theory 2014, 14, 495-506. [CrossRef]

45. Bajde, D. Consumer Culture Theory: Ideology, Mythology and Meaning in Technology Consumption. Int. J. Actor Netw. Theory Technol. Innov. 2014, 6, 10-25. [CrossRef]

46. Patterson, M.; Schroeder, J. Borderlines: Skin, tattoos and consumer culture theory. Mark. Theory 2010, 10, 253-267. [CrossRef]

47. Ahola, E.K. How is the concept of experience defined in consumer culture theory? Discussing different frames of analysis. Kuluttajatutkimus 2005, 1, 91-108.

48. World Cheese Market. Available online: http://www.pmfood.dk/upl/9735/WCMINFORMATION.pdf (accessed on 27 June 2018).

49. Top 20 Cheese Exporting Countries. Available online: https://www.worldatlas.com/articles/top-20-cheeseexporting-countries.html (accessed on 27 June 2018).

50. Countries Who Consume the Most Cheese. Available online: https://www.worldatlas.com/articles/ countries-who-consume-the-most-cheese.html (accessed on 27 June 2018).

51. Polkinghorne, D.E. Language and meaning: Data collection in qualitative research. J. Couns. Psychol. 2005, 52, 129-137. [CrossRef]

52. Teddlie, C.; Yu, F. Mixed methods sampling: A typology with examples. J. Mix. Methods Res. 2007, 1, 77-100. [CrossRef]

53. Tongco, M.D. Purposive sampling as a tool for informant selection. Ethnobot. Res. Appl. 2007, 31, 147-158. [CrossRef]

54. Palinkas, L.A.; Horwitz, S.M.; Green, C.A.; Wisdom, J.P.; Duan, N.; Hoagwood, K. Purposeful sampling for qualitative data collection and analysis in mixed method implementation research. Adm. Policy Ment. Health Ment. Health Serv. Res. 2015, 42, 533-544. [CrossRef] [PubMed]

55. Guest, G.; Bunce, A.; Johnson, L. How many interviews are enough? An experiment with data saturation and variability. Field Methods 2006, 18, 59-82. [CrossRef]

56. Pfeiffer, C.; Speck, M.; Strassner, C. What Leads to Lunch-How Social Practices Impact (Non-) Sustainable Food Consumption/Eating Habits. Sustainability 2017, 9, 1437. [CrossRef]

57. Torquati, B.; Tempesta, T.; Vecchiato, D.; Venanzi, S. Tasty or Sustainable? The Effect of Product Sensory Experience on a Sustainable New Food Product: An Application of Discrete Choice Experiments on Chianina Tinned Beef. Sustainability 2018, 10, 2795. [CrossRef]

58. Górska-Warsewicz, H.; Żakowska-Biemans, S.; Czeczotko, M.; Świątkowska, M.; Stangierska, D.; Świstak, E.; Bobola, A.; Szlachciuk, J.; Krajewski, K. Organic Private Labels as Sources of Competitive Advantage-The Case of International Retailers Operating on the Polish Market. Sustainability 2018, 10, 2338. [CrossRef]

59. Patton, M.Q. Enhancing the quality and credibility of qualitative analysis. Health Serv. Res. 1999, 34, 1189-1208. [PubMed]

60. Hsieh, H.F.; Shannon, S.E. Three approaches to qualitative content analysis. Qual. Health Res. 2005, 15, 1277-1288. [CrossRef] [PubMed]

61. Orlando, G. From the risk society to risk practice: Organic food, embodiment and modernity in Sicily. Food Cult. Soc. 2018, 21, 144-163. [CrossRef]

62. Chan, S.C. Food, memories, and identities in Hong Kong. Identities Glob. Stud. Cult. Power 2010, 17, $204-227$. [CrossRef]

63. Marshall, D. Food as ritual, routine or convention. Consum. Mark. Cult. 2005, 8, 69-85. [CrossRef]

64. Levy, S.J. Revisiting the marketing domain. Eur. J. Mark. 2002, 36, 299-304. [CrossRef]

65. Isherwood, B.; Douglas, M. The World of Goods; Allen Lane: London, UK, 1979.

66. Tajfel, H. Human Groups and Social Categories: Studies in Social Psychology; CUP Archive: Cambridge, UK, 1981.

67. Pillen, H.; Tsourtos, G.; Coveney, J.; Thodis, A.; Itsiopoulos, C.; Kouris-Blazos, A. Retaining Traditional Dietary Practices among Greek Immigrants to Australia: The Role of Ethnic Identity. Ecol. Food Nutr. 2017, 56, 312-328. [CrossRef] [PubMed]

68. Fischler, C. Food, self and identity. Inf. Int. Soc. Sci. Counc. 1988, 27, 275-292. [CrossRef]

69. Phinney, J.S. Ethnic identity in adolescents and adults: Review of research. Psychol. Bull. 1990, 108, 499-514. [CrossRef] [PubMed] 
70. Vural, Y.; Rustemli, A. Identity fluctuations in the Turkish Cypriot community. Mediterr. Politics 2006, 11, 329-348. [CrossRef]

71. Stajcic, N. Understanding culture: Food as a means of communication. Hemispheres. Stud. Cult. Soc. 2013, 28, 77-87.

72. Perry, M.S. Feasting on Culture and Identity: Food Functions in a Multicultural and Transcultural Malaysia. 3L Southeast Asian J. Engl. Lang. Stud. 2017, 23, 184-199. [CrossRef]

73. Wilson, T.M. Food, Drink and Identity in Europe; Rodopi: Amsterdam, The Netherlands, 2006.

(ब) (1)

(C) 2018 by the authors. Licensee MDPI, Basel, Switzerland. This article is an open access article distributed under the terms and conditions of the Creative Commons Attribution (CC BY) license (http:/ / creativecommons.org/licenses/by/4.0/). 